\title{
Islamic Corporate Governance dalam Memoderasi Hubungan antara Kinerja Keuangan dan Islamic Social Reporting
}

\author{
${ }^{1 *}$ Maya Mahardikasari, ${ }^{2}$ Y. Anni Aryani \\ ${ }^{1,2}$ Fakultas Ekonomi dan Bisnis, Universitas Sebelas Maret, Indonesia \\ *Email korenpondensi: mayamahardikasari@gmail.com
}

\begin{abstract}
This purpose of this study is to present empirical evidence the effect of islamic corporate governance in moderating the relationship between financial performance and islamic social reporting on islamic banks in Indonesia. As a moderating variabel, the proxie of islamic corporate governance is the score of sharia supervisory board. The population in this study is islamic banks registered in Otoritas Jasa Keuangan (OJK) during the period 2008-2017. The total of population is 13 companies which are the number of samples from the study. This study uses a data panel model that was analyzed using software Eviews 10. Analysis result prove that financial performance affects on islamic social reporting while islamic corporate governance cannot moderate the relationship between financial performance and islamic social reporting. For the control variables, company size has an effect on islamic social reporting but leverage has no effect on islamic social reporting.
\end{abstract}

Keywords: Islamic Corporate Governance, Financial Performance, Islamic Social Reporting

Saran sitasi: Mahardikasari, M., \& Aryani, Y. (2019). Islamic Corporate Governance dalam Memoderasi Hubungan antara Kinerja Keuangan dan Islamic Social Reporting. Jurnal Ilmiah Ekonomi Islam, 5(02), 102-112. doi: http://dx.doi.org/10.29040/jiei.v5i2.527

DOI: $\underline{\text { http://dx.doi.org/10.29040/jiei.v5i2.527 }}$

\section{Pendahuluan}

Industri keuangan syariah di Indonesia telah mengalami perkembangan dihitung sejak beroperasinya Bank Muamalat sebagai bank syariah pertama di Indonesia. Perkembangan industri perbankan syariah di Indonesia terlihat baik secara global maupun nasional. Secara global, Indonesia menempati urutan ke 6 dalam Thomson Reuters Islamic Finence Developent Report tahun 2016 sebagai negara dengan aset keuangan syariah terbesar di dunia. Sementara secara nasional, perkembangan industri perbankan syariah mengalami peningkatan pada jumlah bank menjadi 13 perbankan dan peningkatan aset sebesar 20,28\% (Roadmap Pengembangan Keuangan Syariah Indonesia, 2017). Banyaknya penduduk Indonesia yang menjadi pemeluk agama mendukung adanya potensi pertumbuhan yang baik pada perbankan syariah. Oleh karena itu, bank syariah harus berupaya untuk lebih menarik minat masyarakat agar berinvestasi di bank syariah. Salah satu upaya yang dapat dilakukan bank syariah adalah dengan memberikan informasi mengenai aktivitas perusahaan kepada masyarakat.

Salah satu aktivitas perusahaan yang harus diinformasikan adalah corporate social responsibility. Untuk perbankan syariah, pengungkapan corporate social responsibility dapat diukur dengan islamic social reporting yang merupakan tolak ukur pelaksanaan tanggung jawab sosial yang berisi kumpulan item-item standar yang ditetapkan oleh AAOIFI (Accounting and Auditing Organization for 
Islamic Financial Institutions) yang selanjutnya dikembangkan lebih luas oleh para peneliti mengenai item-item yang sesuai untuk suatu entitas islam (Othman, Thani, dan Ghani, 2009). Pengungkapan islamic social reporting dapat menjadi strategi bisnis bagi lembaga keuangan syariah dalam menghadapi tuntutan persaingan bisnis yang semakin ketat dan permintaan untuk lebih transparan dari pihak-pihak yang berkepentingan sebab dengan mengungkapkan islamic social reporting yang baik, masyarakat muslim akan percaya bahwa lembaga keuangan syariah dapat mengelola investasi dana mereka sesuai dengan syariah islam.

Aktivitas lain yang harus diinformasikan oleh perbankan syariah adalah good corporate governance. Sebagai salah satu entitas bisnis, perbankan syariah memiliki stakeholder yang mempunyai hak yang harus diberikan perlindungan serta jaminan sehingga sistem manajemen dengan tata kelola yang baik sangat diperlukan (Prasinta, 2012). Islamic corporate governance merupakan bagian dari tata kelola bank syariah yang membedakannya dengan bank konvensional. Islamic corporate governance atau dalam hal ini dewan pengawas syariah adalah lapisan tambahan dari mekanisme pemantauan dan pengawasan yang independen untuk mencegah manajemen perusahaan dari kegiatan investasi yang memiliki risiko besar (Mollah dan Zaman, 2015) ataupun pada kegiatan investasi yang kurang berisiko (Setyawan dan Adityawarman, 2017). Penelitian-penelitian mengenai kinerja keuangan dan pengungkapan corporate social responsibility meliputi penelitian Hackston dan Milne (1996) yang menemukan tidak terdapat hubungan antara kinerja keuangan dan pengungkapan corporate social responsibility namun hasil yang berlawanan ditemukan oleh McGuire, Sundgren, dan Schneeweis (1988) yang menyatakan bahwa terdapat hubungan antara kinerja keuangan dan corporate social responsibility. Sementara penelitian Babalola (2012) menemukan hubungan negatif antara variabel kinerja dan corporate social responsibility. Hubungan negatif juga ditemukan oleh Donovon dan Gibson (2000) yang meneliti hubungan antara profitabilitas dan pengungkapan corporate social responsibility. Akan tetapi dalam penelitian Hermawan dan Mulyawan (2014) yang menyatakan bahwa terdapat hubungan positif antara profitabilitas dengan tanggung jawab sosial perusahaan.

Selain itu, Othman, R, Thani, A, dan Ghani (2009) menunjukkan bahwa islamic corporate government yang ditandai dengan islamic governance score mempunyai pengaruh positif terhadap pengungkapan corporate social responsibility. Sebaliknya, Rizkiningsih (2012) mengungkapkan bahwa islamic governance tidak mempunyai pengaruh signifikan terhadap pengungkapan corporate social responsibility. Sedangkan Mollah dan Zaman (2015) dalam penelitiannya membuktikan bahwa dewan pengawas syariah mempunyai pengaruh positif pada kinerja bank syariah di saat mereka melakukan peran pengawasan, tetapi tidak berpengaruh saat mereka hanya memiliki peran sebagai penasihat.

Pengungkapan

corporate

social responsibility merupakan bagian pedoman dalam melaksanakan good corporate covernance dan islamic corporate governance merupakan salah satu kegiatan dari corporate governance pada bank syariah. Apabila tata kelola perusahaan dilakukan dengan baik maka akan mendorong investor untuk berinvestasi sehingga kinerja perusahaan semakin meningkat karena investor percaya bahwa perusahaan-perusahaan dengan praktik tata kelola perusahaan yang baik mampu mendorong kinerja yang lebih baik dan pengembalian investasi yang lebih baik (Aras dan Crowther, 2008). Apabila kinerja keuangan perusahaan tinggi, maka pengungkapan tanggung jawab sosial perusahaan akan semakin besar. Berdasarkan penjelasan sebelumnya maka penelitian ini akan menguji pengaruh islamic corporate governance dalam memoderasi hubungan atara kinerja keuangan dan islamic social reporting. 


\section{Tinjauan Pustaka}

\subsection{Teori Stakeholder}

Stakeholder adalah setiap kelompok atau individu yang dapat meberikan pengaruh atau diberikan pengaruh oleh kegiatan perusahaan (Freeman, 1984) sehingga secara langsung memberikan pengaruh pada masa depan perusahaan. Aktivitas pengungkapan informasi keuangan, sosial, dan lingkungan merupakan percakapan perusahaan dengan stakeholder-nya sehingga persepsi dan ekspektasi yang stakeholder miliki dapat berubah karena ketersediaan informasi mengenai aktivitas perusahaan (Adam dan McNicholas, 2007). Harapannya adalah dengan melalui pengungkapan informasi-informasi tersebut, perusahaan sanggup memenuhi kebutuhan informasi bagi yang diperlukan oleh stakeholder sehingga memperoleh dukungan dari para stakeholder demi kelangsungan hidup perusahaan. Semakin baik pengungkapan sosial perusahaan maka dukungan pebuh akan diberikan stakeholder dalam segala aktivitas yang bertujuan untuk meningkatkan kinerja dan mencapai laba yang diharapkan perusahaan (Lindawati dan Pupita, 2013).

\subsection{Teori Sinyal (SignallingTheory)}

Teori ini menerangkan bagaimana cara perusahaan dalam memberikan sinyal kepada stakeholder. Zainudin dan Hartono (1999) menyatakan bahwa informasi yang disampaikan sebagai sebuah pengumuman akan memberikan sinyal bagi stakelholder dalam mengambil keputusan investasi. Adanya sinyal berupa informasi terkait kegiatan apapunyang dilakukan perusahaan dalam mencapai tujuan pemilik merupakan pernyataan bahwa perusahaan mempunyai kinerja yang lebih baik dibandingdengan perusahaan lain (Jama'an, 2008). Pihak-pihak yang berkepentingan dapat memperoleh sinyal tentang kondisi keuangan perusahaan dan hal-hal yang mungkin terjadi melaui publikasi informasi yang diberikan perusahaan meliputi laporan keuangan, corporate governance, corporate social responsibility dan informasi lainnya.

\subsection{Islamic Social Reporting (ISR)}

Munculnya kebutuhan tentang pengungkapan tanggung jawab sosial pada perbankan syariah, peneliti-peneliti menggunakan islamic social reporting (ISR) untuk mengukur pengungkapan sosial pada institusi keuangan syariah. Indeks ISR dipercaya bisa menjadi langkah pertama dalam standar pengungkapan corporate social responsibility yang sesuai dengan perspektif islam. ISR merupakan tolak ukur pelaksanaan tanggung jawab sosial yang memuat kumpulan item-item standar pengungkapan sosial yang disusun secara teratur dan ditetapkan oleh AAOIFI (Accounting and Auditing Organization for Islamic Financial Institutions) yang selanjutnya dikembangkan lebih luas oleh para peneliti mengenai item-item pengungkapan yang seharusnya disampaikan oleh suatu entitas Islam (Othman et al, 2009). Haniffa dan Hudaib (2007) menyusun indeks identitas etik yang disebut dengan Ethical Identity Index (EII) dalam mengungkapkan ISR pada bank syariah. Indeks tersebut terdiri dari empat tema yang terdiri dari filosofi dan nilai yang mendasarinya, pembatasan terhadap kesepakatan yang dapat diterima secara Islam, fokus pada tujuan pembangunan dan sosial, dan patuh terhadap arahan dari dewan pengawas syariah.

\subsection{Kinerja Keuangan Perusahaan}

Kinerja keuangan perusahaan adalah pengukuran kinerja perusahaan yang muncul akibat proses pengambilan keputusan manajemen karena berkaitan dengan penggunaan modal, efisiensi dan rentabilitas dari kegiatan perusahaan (Tampubolon, 2005). Pengukuran kinerja menurut Sutrisno (2012) dapat diketahui melalui rasio keuangan, salah satunya adalah rasio profitabilitas. Rasio ini mengukur kemampuan perusahaan dalam memperoleh keuntungan dengan memanfaatkan semua sumber daya yang perusahaan miliki. Salah satu indikator pengukur rasio profitabilitas adalah Return on Asset (ROA). Alasan ROA digunakan sebab rasio ini menunjukkan keberhasilan perusahaan dalam memperoleh keuntungan dari 
aset yang dimiliki perusahaan sehingga memperlihatkan pengukuran kinerja yang lebih baik dan lebih mempresentasikan kepentingan stakeholder karena rasio ini merupakan salah satu teknik yang bersifat comprehensive atau menyeluruh dalam menganalisis keuangan (Wibowo, 2012). Karena sifatnya menyeluruh, teknik analisa ROA dapat mengukur efisiensi penggunaan modal yang bekerja, efisiensi produksi dan efisiensi bagian penjualan sehingga perusahaan telah menjalankan praktek akuntansi dengan baik (Munawir, 2007).

\subsection{Islamic Corporate Governance (ICG)}

Elemen paling penting yang membuat bank syariah berbeda dari bank konvensional adalah adanya pengawasan syariah. Oleh karena itu, dalam sektor keuangan Islam, pengawasan syariah adalah masalah yang sangat penting dalam tata kelola perusahaan yang harus dilakukan oleh dewan pengawas syariah. Pada dasarnya, pengawasan syariah adalah proses memastikan bahwa produk atau layanan keuangan yang diberikan mematuhi prinsipprinsip Islam baik yang melalui konformasinya dengan norma hukum Islam yang diakui atau tidak melanggar pada sesuatu yang sama (DeLorenzo, 2010). Pembentukan dewan pengawas syariah (DPS) merupakan syarat penting dalam pendirian bank syariah. Karena DPS bertanggung jawab untuk mengawasi penerapan berbagai aspek aturan syariah dan menjamin bahwa seluruh transaksi

mematuhi prinsip-prinsip syariah. Grais dan Pellegrini (2006) menyatakan bahwa pada saat ini praktik untuk memastikan bahwa kepatuhan Syariah tergantung pada struktur internal perusahaan, khususnya DPS. Rahman dan Bukair (2013) mengatakan bahwa karakter DPS mempunyai pengaruh terhadap tingkat pengungkapan sosial atau islamic social reporting pada bank syariah. Karakter yang memiliki pengaruh signifikan adalah jumlah anggota, keanggotaan-ganda, kualifikasi doktor, dan reputasi anggota. Keempat karakter ini menentukan kualitas Islamic Governance bank syariah (Farook, Hassan, dan Lanis 2011; Rahman dan Bukair 2013).

\subsection{Pengaruh Kinerja Keuangan terhadap Islamic Social Reporting}

Corporate social responsibility telah menjadi driver penting dalam mempengaruhi opini stakeholder mengenai pemenuhan kewajiban perusahaan, salah satunya adalah kinerja keuangan. Pada saat perusahaan mempunyai tingkat kinerja keuangan yang tinggi, perusahaan (manajemen) menganggap tidak perlu melaporkan hal-hal yamg dapat mengganggu informasi tentang kesuksesan perusahaan. Sebaliknya, saat kinerja keuangan perusahaan rendah, manajemen berharap bahwa para pengguna laporan akan membaca "good news" dari kinerja perusahaan misalnya dalam lingkup sosial sehingga investor akan tetap berinvestasi dalam perusahaan tersebut (Donovan dan Gibson, 2000). Lingkup sosial dalam perbankan syariah dapat diungkapkan melalui islamic social reporting yang merupakan turunan konsep dari corporate social responsibility dengan menggunakan prinsip syariah islam sebagai dasar pedomannya. Oleh karena itu, beberapa item yang ada dalam pengungkapan islamic social reporting berbeda dan tidak terdapat dalam item-item pengungkapan corporate social responsibility. Hal tersebut menunjukkan bahwa terdapat hubungan yang berlawanan antara kinerja keuangan perusahaan dengan tanggung jawab sosial perusahaan.

$H_{1}$ : Kinerja Keuangan berpengaruh negatif terhadap Islamic Social Reporting.

2.7. Pengaruh Islamic Governance dalam memoderasi hubungan antara Kinerja Keuangan dan Islamic Social Reporting

Corporate governance mempunyai peran yang penting hampir di semua lembaga termasuk bank syariah. Adanya dewan pengawas syariah merupakan bagian penting bank syariah yang membedakannya dari bank konvensional karena memiliki fungsi menjamin kesesuaian operasi bank syariah dengan aturan islam. Mekanisme yang dijamin oleh dewan pengawas syariah 
inilah yang disebut sebagai islamic corporate governance. Pada penelitian Jabbar (2009) menyatakan bahwa ada kesenjangan konsep teori dan praktek yang dilakukan bank syariah. Salah satunya adalah lemahnya kontrol pengawasan dan kurang kuatnya komitmen stakeholder. Oleh sebab itu, tugas perbankan syariah saat ini adalah menghilangkan keraguan dan meyakinkan masyarakat mengenai implementasi produk sesuai dengan syariah sehingga eksistensi dewan pengawas syariah menjadi sangat penting karena dapat membuat masyarakat islam percaya bahwa bank syariah akan mengelola dana mereka sesuai dengan syariat islam. Hal tersebut akan menarik minat masyarakat islam untuk berinvestasi. Apabila banyak masyarakat yang berinvestasi, maka secara otomatis aktivitas bisnis dalam bank syariah akan meningkat dan pada akhirnya akan meningkatkan kinerja keuangan perusahaan kemudian pengungkapan ISR pada bank syariah dapat menjadi lebih luas.

$\mathrm{H}_{2}$ : Islamic Corporate Governance dapat memoderasi hubungan antara Kinerja Keuangan dan Islamic Social Reporting.

\section{Metode Penelitian}

\subsection{Sampel Penelitian}

Populasi dalam penelitian ini adalah perusahaan yang masuk dalam bank umum syariah yang terdaftar di Otoritas Jasa Keuangan (OJK) tahun 2008-2017 sebanyak 13 perusahaan. Pemilihan sampel pada penelitian ini memakai purposive sampling method dengan maksud untuk menperoleh sampel yang representive sesuai dengan kriteria yang telah ditentukan. Kriteria pengambilan sampel berdasarkan: bank umum syariah di Indonesia yang telah menerbitkan annual report periode 2008-2017 yang telah diaudit, berakhir pada tanggal 31 Desember, mempunyai data annual report yang lengkap dan data yang dibutuhkan dalam penelitian.

\subsection{Definisi Operasional dan Pengukuran Variabel}

3.2.1. Variabel Dependen dan Independen

Variabel dependen adalah variabel yang menjadi perhatian utama peneliti (Sekaran, 2011) Variabel dependen dalam penelitian ini adalah Islamic Social Reporting (ISR). Islamic social reporting adalah turunan konsep dari corporate social responsibility yang menggunakan prinsip syariah islam sebagai dasar pedomannya yang ditujukan untuk perusahaan-perusahaan syariah. Islamic social reporting diukur dengan menggunakan Ethical Identity Index (EII) yang dikembangkan oleh Haniffa dan Hudaib (2007).

Variabel independen (X) adalah variabel yang memberikan pengaruh positis atau negatif terhadap variabel dependen (Sekaran, 2011). Variabel independen dalam penelitian adalah kinerja keuangan perusahaan yang diukur dengan rasio keuangan. Rasio yang digunakan adalah Return on Asset (ROA).

Variabel moderating adalah variabel independen yang akan memperkuat atau memperlemah hubungan antara variabel independen lainnya terhadap variabel dependen (Ghozali, 2013). Variabel moderating pada penelitian ini yaitu Islamic Corporate Governance (ICG) yang merupakan turunan konsep dari good corrporate governance yang dasar aturannya menggunakan hukum islam. Variabel tersebut diukur berdasarkan total nilai dari setiap karakter sharia supervisory board atau dewan pengawas syariah yang tedapat dalam penelitian Farook, et al (2011) dan Rahman dan Bukair (2013).

\subsubsection{Variabel Kontrol}

Variabel kontrol merupakan variabel yang dibuat konstan agar pengaruh variabel independen terhadap variabel dependen tidak dipengaruhi oleh faktor luar yang tidak diteliti. Variabel kontrol dalam penelitian ini adalah ukuran perusahaan (size) dan leverage. Definisi operasional variabel dalam penelitian adalah sebagai berikut. 


\section{Jurnal Ilmiah Ekonomi Islam, 5(02), 2019, 81}

Tabel 1. Definisi Operasional Variabel

\begin{tabular}{|l|l|}
\hline Variabel & Pengukuran \\
\hline Variabel Dependen & $\begin{array}{l}\text { Jumlah item disclosure yang terpenuhi / jumlah item } \\
\text { maksimum }\end{array}$ \\
\hline Islamic Social Reporting & Laba bersih / total aset \\
\hline Variabel Independen & $\begin{array}{l}\text { Jumlah skor karakter dewan pengawas syariah yang } \\
\text { terpenuhi / jumlah skor maksimum }\end{array}$ \\
\hline Raturn on Asset & \\
\hline Variabel Moderating & Logaritma total asset \\
\hline Islamic Corporate Governance & Total liabilitas / total asset \\
\hline Variabel Kontrol & \\
\hline Ukuran Perusahaan (SIZE) & \\
\hline Leverage (LEV) &
\end{tabular}

Sumber: Hasil olah data Eviews 10

\subsection{Teknik Analisis}

Pada penelitian ini terdapat variabel moderating sehingga metodee yang digunakan adalah moderated regression analysis. Model moderated regression analysis dirumuskan sebagai berikut:

\section{Regresi model I :}

ISR $=\alpha+\beta 1$ ROA $+\beta 2$ IGScore $+\beta 3$ SIZE + $\beta 4 L E V+\mathrm{e}$

\section{Regresi model II :}

ISR $=\alpha+\beta 1 \mathrm{ROA}+\beta 2 \mathrm{IGScore}+\beta 3$ (ROA $*$ IGScore $)+\beta 4 S I Z E+\beta 5 L E V+\mathrm{e}$

Keterangan:

$\alpha \quad$ : konstanta

$\beta \quad$ : konstanta variabel

ISR : Islamic Social Reporting

ROA : Return on Assets

IG Score : Islamic Governance Score

SIZE : Ukuran Perusahaan

LEV : Leverage

e : residual error

\section{Hasil dan Pembahasan}

\subsection{Statistik Deskriptif}

Populasi pada penelitan ini adalah 13 bank umum syariah dengan periode pengamatan 10 tahun yaitu dari tahun 2008 sampai tahun 2017 yang diperlihatkan dalam tabel 2. Dalam penelitian ini populasi merupakan sampel penelitian sehingga dapat diketahui bahwa total sampel awal sebanyak 130 sampel. Setelah disesuaikan dengan kriteria pemilihan sampel maka sampel yang akan digunakan berubah menjadi 98 sampel karena ada beberapa sampel yang dikeluarkan sebab tidak semua perusahaan yang dijadikan sampel menerbitkan annual report setiap tahun dan secara lengkap.

Tabel 2. Pemilihan Sampel

\begin{tabular}{|l|l|l|}
\hline No & Kriteria & Jumlah \\
\hline 1 & $\begin{array}{l}\text { Bank umum syariah yang } \\
\text { terdaftar di OJK }\end{array}$ & 13 \\
\hline 2 & $\begin{array}{l}\text { Sampel awal penelitian selama } \\
10 \text { tahun }\end{array}$ & 130 \\
\hline 3 & $\begin{array}{l}\text { Dikurangi: } \\
\text { Sampel yang tidak memiliki } \\
\text { annual repot secara lengkap }\end{array}$ & $(32)$ \\
\hline Jumlah sampel akhir & 98 \\
\hline
\end{tabular}

Sumber: Hasil olah data Eviews 10

Statistik deskriptif dari data sampel penelitian ini ditunjukkan oleh tabel 3 . Berdasarkan tabel tersebut dapat diketahui bahwa islamic social reporting (ISR) mempunyai nilai mean sebesar 0,541601 dengan standar deviasi sebesar 0,093689. Standar deviasi menunjukan heterogenitas dalam penelitian. Hal ini berarti rata-rata bank syariah yang melakukan pengungkapan islamic social reporting masih sangat rendah. Variabel kinerja keuangan (ROA) memiliki nilai mean sebesar 0,003598, dengan nilai maksimum dan minimum masing-masing 0,099241 dan $-0,168857$. Variabel islamic corporate governance (IGSCORE) sebagai variabel moderating memiliki nilai mean sebesar 0,926531, dengan nilai maksimum dan minimul 


\section{Jurnal Ilmiah Ekonomi Islam, 5(02), 2019, 108}

masing-masing 1,000000 dan 0,400000. Variabel ROA dan IGSCORE merupakan variabel dummy. Variabel kontrol ukuran perusahaan (SIZE) yang memiliki nilai mean sebesar 29,60335, dengan nilai maksimum dan minimum masing-masing
32,10767 dan 26,85169. Variabel kontrol lainnya yaitu variabel leverage (LEV) memiliki nilai mean sebesar 0,178713, dengan nilai maksimum dan minimum masing-masing 0,858604 dan 0,027965 .

Tabel 3. Hasil Analisis Deskriptif

\begin{tabular}{|l|c|c|c|c|c|}
\hline & ISR & ROA & IGSCORE & SIZE & LEV \\
\hline Mean & 0.541601 & 0.003598 & 0.926531 & 29.60335 & 0.178713 \\
\hline Maximum & 0.692308 & 0.099241 & 1.000000 & 32.10767 & 0.858604 \\
\hline Minimum & 0.307692 & -0.168857 & 0.400000 & 26.85169 & 0.027965 \\
\hline Std. Dev. & 0.093689 & 0.030470 & 0.147523 & 1.284804 & 0.099921 \\
\hline Sampel & \multicolumn{5}{|l}{} \\
\hline
\end{tabular}

Sumber: Hasil olah data Eviews 10

\subsection{Hasil Penelitian}

Berdasarkan Tabel 4 di bawah ini dapat diketahui bahwa pada model I nilai adjusted $R$ squared sebesar 0,575 atau sekitar 58\% dari variabel dependen (ISR) dapat dijelaskan oleh variabel independen (ROA). Begitu pula pada model II, nilai adjusted $R$-squared-nya sebesar 0,579 atau sekitar $58 \%$ dari variabel dependen (ISR) dapat dijelaskan oleh variabel independen (ROA) dan variabel moderasi (IGSCORE). Sisanya, $42 \%$ dipengaruhi oleh variabel lain yang tidak termasuk ke dalam model. Hasil uji $\mathrm{F}$ pada Tabel 4 menunjukkan bahwa nilai $F_{\text {hitung }}$ pada model I sebesar 34,38915 dengan tingkat signifikansi sebesar 0,000000 dan $F_{\text {hitung }}$ pada model II sebesar 27.28887 dengan tingkat signifikansi sebesar 0,000000. Tingkat signifkansi pada kedua model tersebut $<5 \%$ yang menunjukkan bahwa kedua model regresi pada penelitian ini layak digunakan untuk memprediksi variabel independen dan variabel moderasi. Sehingga variabel independen, variabel moderasi dan variabel kontrol pada penelitian ini secara simultan berpengaruh signifikan terhadap ISR.

Tabel 4. Hasil Uji Hipotesis Penelitian

\begin{tabular}{|c|c|c|c|c|}
\hline \multirow{2}{*}{ Variable } & \multicolumn{2}{|l|}{ Model I } & \multicolumn{2}{|c|}{ Model II } \\
\hline & Coefficient & Prob. & Coefficient & Prob. \\
\hline $\mathrm{C}$ & -1.1574990 .0000 & & -1.168753 & 0.0000 \\
\hline ROA & $-0.4430240 .0643^{*}$ & & 0.771194 & 0.6138 \\
\hline IGSCORE & 0.1405920 .0010 & & 0.143028 & 0.0024 \\
\hline ROA*IGSCORE & & & -1.283016 & 0.4470 \\
\hline SIZE & 0.0534640 .0000 & & 0.053699 & 0.0000 \\
\hline LEV & -0.0613250 .2316 & & -0.054839 & 0.3215 \\
\hline R-squared & 0.596628 & & 0.597 & \\
\hline Adjusted R-squared & 0.579279 & & 0.575 & \\
\hline F-statistic & 34.38915 & & 27.28 & \\
\hline Prob(F-statistic) & 0.000000 & & 0.000 & \\
\hline
\end{tabular}

*mengindikasikan bahwa signifikan di level 10\% 


\subsection{Pembahasan}

Hasil dari uji statistik $t$ pada Tabel 4 menunjukkan bahwa hasil perhitungan regresi pengaruh Kinerja Keuangan (ROA) terhadap Islamic Social Reporting (ISR) dengan menggunakan program Eviews 10 mempunyai nilai probabilitas 0,0643 yang kurang dari tingkat signifikansi $(0,10)$ koefision penelitian meunjukkan arah negatif, maka $\mathrm{H} 1$ diterima. Hasil tersebut menunjukkan bahwa semakin besar kinerja keuangan yang diperoleh bank umum syariah tidak membuat bank mengungkapkan tanggung jawab islam perusahaan atau ISR dengan lebih luas. Karena hal tersebut mungkin menyebabkan adanya pengenaan biaya ekonomi sehingga menurunkan laba perusahaan (Freedman dan Jaggi, 1988) serta lemahnya kontrol pengawasan dan kurang kuatnya komitmen stakeholder (Jabbar, 2009). Oleh sebab itu, selama perusahaan memiliki kinerja keuangan yang tinggi maka perusahaan hanya cukup melaporkan informasi terkait kesuksesan dalam mendapatkan keuntungan, tidak perlu mengungkapkan informasi yang lain. Sesuai dengan penelitian Donovan dan Gibson (2000) yang menemukan bahwa profitabilitas berpengaruh negatif terhadap pengungkapan tanggung jawab sosial perusahaan. Pada saat perusahaan mempunyai tingkat laba yang tinggi, perusahaan (manajemen) menganggap tidak perlu melaporkan hal-hal yang dapat mengganggu informasi tentang kesuksesan perusahaan. Sebaliknya, pada saat tingkat profitabilitas rendah, mereka berharap bahwa para pengguna laporan akan membaca "good news" dari kinerja perusahaan, misalnya dalam lingkup sosial. Dalam hal ini, "Good news" yang dimaksud pada bank syariah adalah pengungkapan Islamic Social Reporting (ISR) yang didalamnya memberikan informasi bahwa kegiatan perusahaan sesuai prinsip syariah islam sehingga diharapkan investor akan tetap berinvestasi dalam bank syariah saat bank berada pada kinerja keuangan yang rendah. Apabila investor tetap berinvestasi maka bank syariah dapat menjalankan kegiatan operasionalnya untuk meningkatkan pendapatan. Pendapatan yang diperoleh bank syariah berasal dari biaya administrasi terhadap penyaluran kredit al-qardh, mark up terhadap penyaluran kredit almurabahah dan al-ba'i bi saman 'ajil, bagi hasil dari penyaluran kredit almudharabah dan almusyarakah serta fee terhadap penggunaan jasajasa perbankan umumnya (Perwataatmadja dan Antonio, 1992). Semua hal tersebut merupakan produkproduk yang ditawarkan oleh bank syariah yang merupakan aset yang dimiliki oleh bank syariah.

Hasil uji pengaruh Islamic Corporate Governance (ICG) dalam memoderasi hubungan antara kinerja keuangan (ROA) dan islamic social reporting (ISR) menunjukkan nilai probabilitas IGSCORE pada model I sebesar 0,0010 lebih rendah dari tingkat signifikansi $(0,10)$ yang berarti hasilnya signifikan dan nilai probabilitas ROA*IGCORE sebesar 0,4470 lebih tinggi dari tingkat signifikansi $(0,10)$ yang menunjukkan hasil tidak signifikan. Dalam pembagian kelompok yang dijelaskan oleh Sugiono (2004), hasil tersebut menunjukkan bahwa ICG bukan variabel moderator, tapi ia merupakan suatu variabel independen, intervening, exogenous, antecedent, atau prediktor. Hal ini berarti ICG tidak memoderasi hubungan antara kinerja keuangan dan ISR sehingga $\mathrm{H} 2$ ditolak.

Aspek kunci dalam pelaksanaan GCG pada bank syariah yaitu keberadaan ICG atau dalam hal ini Dewan Pengawas Syariah (DPS). Adanya DPS menjadi solusi dalam mengatasi kontrol pengawasan yang lemah dan komitmen yang kurang kuat dari para stakeholder. Apabila DPS dapat menjalankan fungsinya dengan baik, maka masyarakat islam akan percaya pada pengelolaan yang dilakukan bank syariah sesuai dengan aturan islam. Kemudian masyarakat islam akan menginvestasikan dana mereka pada bank syariah dan apabila banyak masyarakat yang berinvestasi, maka secara otomatis aktivitas bisnis dalam bank syariah akan meningkat dan pada akhirnya akan meningkatkan kinerja keuangan perusahaan kemudian melakukan 
pengungkapan ISR secara lebih luas di bawah pengawasan dewan pengawas syariah.

Namun hasil penelitian ini menemukan bahwa ICG tidak dapat memoderasi hubungan antara kinerja keuangan dan ISR. Hal ini disebabkan oleh belum optimalnya peran dan fungsi DPS karena DPS hanya berkonsentrasi pada persetujuan dan pemberian rekomendasi produk-produk yang sesuai dengan syariah sehingga untuk pengawasan kinerja keuangan dan tanggung jawab sosial secara islam masih terasa kurang. Selain itu, jumlah DPS pada sebagian besar bank syariah masih belum memenuhi kriteria dari badan internasional Accounting and Auditing Organization for Islamic Finance Institutions (AAOIFI) yang menyatakan setidaknya terdapat tiga orang anggota DPS pada bank syariah, sedangkan sebagian besar bank syariah di Indonesia ratarata hanya memiliki dua orang anggota sehingga pengawasan terhadap aktivitas dan tannggung jawab sosial bank syariah masih belum terkontrol.

\section{Kesimpulan}

Penelitian ini dilakukan untuk mendapatkan bukti empiris mengenai pengaruh islamic corporate governance dalam memoderasi hubngan antara kinerja keuangan perusahaan dan islamic social reporting pada bank umum syariah yang terdaftar di Otoritas Jasa Keuangan tahun 2008-2017. Hasil pengujian analisis membuktikan bahwa hipotesis pertama pada penelitian ini diterima. Kinerja keuangan perusahaan (ROA) berpengaruh negatif terhadap islamic social reporting yang berarti semakin besar kinerja keuangan yang dimiliki bank umum syariah tidak membuat bank syariah mengungkapkan tanggung jawab islam perusahaan atau ISR dengan lebih luas.

Untuk hipotesis kedua pada penelitian ini ditolak karena hasil menunjukkan bahwa islamic corporate governance bukan variabel moderator, tapi ia merupakan suatu variabel independen, intervening, exogenous, antecedent, atau prediktor sehingga diperoleh kesimpulan bahwa islamic corporate governance tidak memoderasi hubungan antara kinerja keuangan (ROA) dan islamic social reporting. Sedangkan untuk variabel kontrol ukuran perusahaan berpengaruh signifikan terhadap islamic social reporting dan leverage tidak berpengaruh signifikan terhadap islamic social reporting.

Penelitian ini mempunyai beberapa keterbatasan sebagai berikut.

a. Sampel penelitian ini hanya terbatas pada bank syariah di Indonesia sehingga tidak dapat diketahui perbandingan perkembangan bank syariah dengan negara lain.

b. Variabel independen yang digunakan dalam penelitian ini hanya menggunakan satu ukuran akuntansi yaitu ROA sebagai ukuran kinerja keuangan sedangkan masih terdapat ukuran kinerja yang berdasarkan maqashid syariah.

c. Penelitian ini menggunakan item ISR yang dikembangkan oleh Haniffa dan Hudaib (2007) yang mungkin tidak mencakup itemitem yang sesuai dengan keadaan perbankan syariah sekarang serta terdapat subjektifitas dalam menentukan luas pengungkapan pada penelitian ini.

Berdasarkan pada keterbatasan yang ada di dalam penelitian ini, maka saran untuk penelitian selanjutnya adalah memperluas sampel penelitian, tidak hanya dari Indonesia tapi bank syariah negara lain juga disertakan sehingga dapat diketahui perbandingan perkembangan bank syariah antara negara yang satu dengan negara yang lain. Menggunakan atau menambah ukuran kinerja keuangan secara akuntansi lain seperti ROE dan ROI. Selain itu dapat menggunakan ukuran kinerja yang diukur berdasarkan maqashid syariah. Selain itu, pada penelitian mendatang diharapkan menggunakan itemitem pengungkapan ISR lain yang lebih terbaru yang telah disesuaikan dengan keadaan bank syariah saat ini serta melibatkan pihak lain dalam memerikasa kembali luas pengungkapan yang dilakukan sehingga subjektifitas penelitian dapat terminimalisir. 


\section{Ucapan Terimakasih}

Penulis menyampaikan terimakasih pada semua pihak yang telah memberikan bantuan dan doa, khususnya kepada Program Studi Akuntansi Fakultas Ekonomi dan Bisnis Universitas Sebelas Maret yang telah membantu hingga terselesainya penelitian ini.

\section{Daftar Pustaka}

Adam, C.A. dan McNicholas, P. (2007). Making a Difference: Sustainability Reporting, Accountability and Organizational Change. Accounting, Auditing \& Accountability Journal. Volume 20, No. 3: 382 - 402.

Aras, Guler dan Crowther, David. (2008). Developing Sustainable Reporting Standards. Journal of Applied Accounting Research. Volume 9, No.1: 4-16.

Babalola, Yisou Abiodun. (2012). The Impact of Corporate Social Responsibility on Firms' Profitability in Nigeria. European Journal of Economics, Finance and Administrative Sciences 45.

DeLorenzo, Y. T. (2010). Shari'ah Supervision in Modern Islamic Finance. Diakses pada tanggal 13 April 2019 dari www.guidanceresidential.com.

Donovan, Gary dan Gibson, Kathy. (2000). Environmental Disclosure in the Corporate Annual Report: A longitudinal Australian Study. Paper for Presentation in the 6th Interdiciplinary Environmental Association Conference.

Farook, S, M K. Hassan, dan R. Lanis. (2011). Determinants of Corporate Social Responsibility Disclosure: The Case of Islamic Banks. Journal of Islamic Accounting and Business Research. Volume 2. No. 2: 114-141.

Freedman, M. and Jaggi. M. (1988). An Analysis of The Association between Pollution Disclosure and Economic Performance. Accounting, Auditing \& Accountability Journal. Volume 1. No. 2: 43-58.

Freeman, R. E. (1984). Strategic Management: A Stakeholder Approach. Boston: Pitman Publishing.
Ghozali dan Chariri. (2007). Teori Akuntansi. Semarang: Badan Penerbit Universitas Diponegoro.

Ghozali, Imam. (2013). Aplikasi Analisis Multivariate Dengan Program SPSS. Edisi Ketujuh. Semarang: Badan Penerbit Universitas Diponegoro.

Grais, Wafik dan Pellegrini, Matteo. (2006). Corporate Governance and Sharia Compliance in Institution Offerig Islamic Financial Service. World Bank Policy Research Working Paper 4045.

Hackston, D. dan M.J. Milne. (1996). Some Determinants of Social and Environmental Disclosures in New Zealand Companies. Accounting, Auditing, and Accountability Journal, Volume 9, No. 1: 77 - 108.

Haniffa, R, and M. Hudaib. (2007). Exploring The Ethical Identity of Islamic Banks Via Communication in Annual Reports. Journal of Business Ethics. Volume 76. No. 1: 97116.

Haniffa, R. M. (2002). Social Responsibility Disclosure: An Islamic Perspective. IMAR Journal. Volume 1, No. 2: 128-46.

Hermawan, Marko S. dan Mulyawan, Stephani G. (2014). Profitability and Corporate Social Responsibility: An Analysis of Indonesia's Listed Company. Asia Pasific Journal of Accounting and Finance. Volume 3, No. 1.

ICD Thomson Reuters. (2017). Thomson Reuters Islamic Finance Development Report 2017.Diakses pada tanggal 15 April 2019 dari https://cheif.iba.edu.pk.

Jabbar, Khalil D.J. (2009). Modern Murabahah a Fiducory Sale or a Misnomer (Permissible Financing Method). Lexicus Islamicus Opaluque Islamic Finance Intelligence. Volume 1.

Jama'an. (2008). Pengaruh Mekanisme Corporate Governance, dan Kualitas Kantor Akuntan Publik terhadap Integritas Informasi Laporan Keuangan (Studi Pada Perusahaan Publik Di BEJ). Jurnal Akuntansi dan Keuangan, 43-52. 
Lindawati, Ang Swat Lin dan Pupita, Marsella Eka. (2015). Corporate Social Responsibility: Implikasi Stakeholder dan Legitimacy Gap dalam Peningkatan Kinerja Perusahaan. Jurnal Akuntansi Multiparadigma. Volume 6, No. 1: 157-174.

Maali, B., P. Casson, dan C. Napier. (2006). Social Reporting by Islamic Banks. Abacus. Volume 42. No. 2: 266289.

McGuire, Jean B., A. Sundgren, dan T. Schneeweis. (1988). Corporate Social Responsibility and Firm Financial Performance. Academy of Management Journal. Volume 31. No. 4: 854-872.

Mollah, Sabur dan Zaman, Mahbub. (2015). Shari'ah Supervision, Corporate Governance and Performance: Conventional vs Islamic Banks. Journal of Banking and Finance. Volume 58, 418-35.

Munawir. (2007). Analisis Laporan Keuangan. Yogyakarta: Liberty.

Othman, R., Md-Thani, A., dan Ghani, E. K. (2009). Determinants of Islamic Social Reporting Among Top Shari'a-Approved Companies in Bursa Malaysia. Research Journal of International Studies, Volume 12, 4-20.

Otoritas Jasa Keuangan (OJK). (2017). Roadmap Pengembangan Keuangan Syariah 20172019. Diakses pada tanggal 12 Desember 2018 dari www.ojk.go.id.

Pemerintah Indonesia. (2007). Undang-undang Republik Indonesia No. 40 tahun 2007 tentang Perseroan Terbatas. Jakarta: Sekretariat Negara.

Pemerintah Indonesia. (2012). Peraturan Pemerintah (PP) Nomor 47 tahun 2012 tentang Tanggungjawab Sosial dan Lingkungan. Jakarta: Sekretariat Negara.

Perwataatmadja, Karnaen dan Antonio, Muhammad Syafi'i.(1992). Apa dan Bagaimana Bank Islam. Yogyakarta: Dana Bhakti Wakaf UII.

Prasinta, Dian. (2012). Pengaruh Good Corporate Governance terhadap Kinerja Keuangan. Accounting Analysis Journal.Volume 1, No. 2.
Rahman, A. A., dan A. A. Bukair. (2013). The Influence of The Shariah Supervision Board on Corporate Social Responsibility Disclosure by Islamic Banks of Gulf CoOperation Council Countries. Asian Journal of Business and Accounting. Volume 6. No. 2: $65-105$.

Rizkiningsih, Priyesta. (2012). Factor-Faktor yang Mempengaruhi Pengungkapan Islamic Sosial Reporting (ISR) : Studi Empiris Pada Bank Syariah di Indonesia, Malaysia dan Negara-Negara Gulf Cooperation Council. Universitas Indonesia.

Sekaran, Uma. (2011). Research Methods for Business Edisi I and 2. Jakarta: Salemba Empat.

Setyawan, C. D. dan Adityawarman. (2017). Pengaruh Dewan Komisaris dan Investment Account Holders Terhadap Kinerja Bank Syariah di Indonesia. Diponegoro Journal Of Accounting. Volume 6, No. 3: 1-11.

Sugiono. (2004). Konsep, Identifikasi, Alat Analisis dan Masalah Penggunaan Variabel Moderator. Jurnal Studi Manajemen dan Organisasi. Volume 1, No. 2: 61-70.

Sugiyono. (2012). Metode Penelitian Kuantitatif Kualitatif dan $R \& B$. Bandung: Alfabeta.

Sutrisno. (2012). Manajemen Keuangan Teori, Konsep, dan Aplikasi. Yogyakarta: EKONISIA.

Tampubolon, Manahan P. (2005). Manajemen Keuangan. Jakarta: Ghalia Indonesia.

Wibowo. (2012). Manajemen Kinerja. Jakarta: Raja Grafindo Persada.

www.bps.go.id

www.ojk.go.id

Zainudin dan Hartono, Jogiyanto. 1999. Manfaat Rasio Keuangan dalam Memprediksi Pertumbuhan Laba. Jurnal Riset Akuntansi Indonesia. 